5. Peduzzi P, Shatney C, Sheagren J, Sprung C. Predictors of bacteremia and Gram-negative bacteremia in patients with sepsis. A rch Intern M ed 1992:152:529-535.

6. Mellors JW, Horowitz RJ, Harvey MR, et al. A simple index to identify occult bacterial infection in adults with acute unexplained fever. Arch Intern M ed 1987;147:666-671.

7. Leibovici L, Cohen O, Wysenbeek AJ. Occult bacterial infection in adults with unexplained fever. Validation of a diagnostic index. A rch Intern M ed 1990;150:1270-1272.

8. Aube H, Milan C, Blettery B. Risk factors for septic shock in the early management of bacteremia. Am $J$ M ed 1992;93:283-288.

9. Leibovici L, Konisberger H, Pitlik SD, Samra Z, Drucker M. Predictive index for optimizing empiric treatment of Gramnegative bacteremia. J Infect D is 1991;163:193-196.

10. Gransden WR, Phillips I. Predictive index for optimizing empiric treatment of Gram-negative bacteremia. J Infect Dis 1991;164:211 212. Letter.

11. Gransden WR. Predictive indices for optimizing empiric treatment of bacteremia. Infections in M edicine 1992; May:61-68.

12. Bates DW, Cook F, Goldman L, Lee TH. Predicting bacteremia in hospitalized patients. A prospectively validated model. Ann Intern M ed 1990;113:495-500.

13. Gross PA, Barrett TL, Dellinger P, et al. Quality standard for the treatment of bacteremia. Infect Control Hoșp Epidemiol 1994:15:189-192.

14. McCabe WR, Jackson GG. Gram-negative bacteremia, I: etiology and ecology. Arch Intern M ed 1962:110:847-855.

15. Knaus WA, Draper WA, Wagner DP, Zimmerman JE. APACHE 11: a severity of disease classification system. Crit Care M ed 1985;13:818-829.

16. MacGregor RR, Beaty HN. Evaluation of positive blood cultures. Guidelines for early differentiation of contaminated from valid positive cultures. Arch Intern M ed 1972;130:84-87.

17. Centor RM, Schwartz JS. An evaluation of methods for estimating the area under the receiver operating characteristic (ROC) curve. M ed Decis M aking 1985;5:149-156.

18. Centor RM. A Visicale program for estimating the area under a receiver operating charateristic (ROC) curve. M ed Decis M aking 1985;5:139-148.

19. Nettleman MD. Receiver operator characteristic (ROC) curves. Infect Control H osp Epidemiol 1988;9:374-377.

20. Hanley JA, McNeil BI. The meaning and use of the area under the receiver operating characteristic (ROC) curve. Radiology 1982:143:29-36.

21. Bates DW, Goldman L, Lee TH. Contaminant blood cultures and resource utilization. The true consequences of false-positive results. JAMA 1991;265:365-369.

22. Bates DW, Lee TH. Rapid classification of positive blood cultures. Prospective validation of a multivariate algorithm. JAMA 1992;267:1962-1966.

23. Fontanarosa PB, Kaeberiein FJ, Gerson LW, Thomson RB. Difficulty in predicting bacteremia in elderly emergency patients. Ann Emerg M ed 1992;21:842-848.

24. Centers for Disease Control. Increase in national hospital discharge survey rates for septicemia-United States, 1979-87. M M WR 1990;39:31-34.

25. Gross PA, Barrett TL, Dellinger P, et al. Consensus development of quality standards. Infect Control Hosp Epidemiol 1994;15:180181 .

26. Aronson MD, Bor DH. Blood cultures. Ann Intern M ed 1987; 106:246-253

27. Lorian V, Amaral L. Predictive value of blood cultures. Infect Control H osp E pidemiol 1992;13:293-294.

\title{
Seventy-Nine New Drugs and Vaccines Are Being Developed for Infectious Diseases
}

\section{by Gina Pugliese, RN, MS Medical News Editor}

Seventy-nine new drugs and vaccines for infectious diseases are currently in development by 49 US pharmaceutical research firms, according to a recent survey by the Pharmaceutical Research and Manufacturers of America (PhRMA) (formerly the Pharmaceutical Manufacturers Association). Of the nearly $\$ 14$ billion the industry will invest in research this year, more than $\$ 2$ billion will be devoted to medicines for infectious diseases.

The survey found 28 antibacterials, 2 vaccines and other biologics, 16 antivirals, 11 antifungals, and 2 immune enhancers. They include the first vaccine for Lyme disease, the first vaccine for hepatitis $\mathrm{A}$, and medicines that target infections caused by drugresistant bacteria. Drugs for AIDS were excluded from this survey but were released in a separate report.

Infectious diseases are the pharmaceutical industry's third biggest area of research investment, outstripped only by research on medicine for heart disease and stroke and for diseases of the central nervous system. Although the pharmaceutical industry will spend a record $\$ 14$ billion in research and development (R\&D) of new medicines this year, this figure represents the smallest rate of increase-approximately $9 \%$-since 1977. In contrast, from 1980 to 1992 , R\&D expenditures increased by an average of more than $16 \%$ per year.

Dr. Richard Dumb, executive direc- tor of the National Foundation for Infectious Disease (NFID), spoke at the press conference where the survey data was released. Dr. Dumb noted that infectious diseases account for $25 \%$ of all visits to physicians each year and that antimicrobial agents are the second most frequently prescribed class of drugs in the country Annually, more than 740 million infectious diseases events occur, resulting in an estimated 200,000 deaths and costing more than $\$ 17$ billion in direct care. They result in 2 million years of life lost before age 65 , more than 52 million hospital days, and nearly 2 billion days lost from work, school, or other major activities.

FROM: NFID. Survey reports on ID medicines and vaccines in testing. The Double Helix 1994;19:2. 